\title{
Bir Cumhuriyet Kadınını Yazılarından Tanımak: İffet Halim Oruz ve Kadın Gazetesi’ndeki Yazıları (1947-1963)*
}

\author{
Recognizing a Republican Woman from Her Writings: Iffet Halim Oruz and Her \\ Writings in Women Newspaper (1947-1963)
}

\author{
Dr. Öğr Üyesi Sezen KARABULUT ${ }^{(D)}$
}

\begin{abstract}
$\ddot{O} \mathbf{z}$
Türk Modernleşme sürecinin başlaması ile birlikte eğitim, kültür ve sosyal alanda yaşanan değişim ve dönüşümler beraberinde aydın bir sınıfın yetişmesine zemin hazırlamıştır. Bu aydın zümrenin içerisinde kadınların da yer aldığı görülmektedir. Dönemin öncüleri, edebi alanda başladıkları çalışmalarını kadın hareketi alanında da sürdürmüşler ve kadının kamusal alanda aktif olarak yer almasında önemli adımlar atılmasını sağlamışlardır. Aydın kadınlar denilince İffet Halim Oruz bu figürler arasında en çok akla gelenlerden biridir. Oruz'un gerek Türk Kadınlar Birliği'ndeki çalışmaları gerekse de kadın yayınları konusundaki çalışmaları dikkate değerdir. Tanzimat'la birlikte başlayan kadın yayıncılığı süreç içerisinde önemli bir gelişme göstermiştir. Ancak kadınlara yönelik hazırlanan bu yayınların önemli bir kısmı dergi formatında çıkarılmış ve içerik olarak sınırlı kalmıştır. İffet Halim Oruz başkanlığında 1 Mart 1947’de yayın hayatına başlayan Kadın Gazetesi ise önemli bir ilki gerçekleştirerek büyük boy, siyasi ve sosyal konulara öncelikli olarak yer vererek geniş bir içerik ile uzun yıllar yayın hayatına devam etmiştir. Bu çalışmada Cumhuriyet döneminin aydın Türk kadınlarından biri olan İffet Halim Oruz'u ve Kadın Gazetesi'ndeki çalışmalarını tanıtmak amaçlanmıştır. Bunun için İffet Halim Oruz'un 1947-1963 yılları arasında Kadın Gazetesi'nde yayınlanmış sosyal, siyasi ve eğitim hayatında kadının yeri konularını işleyen yazıları kategorik olarak incelenmişstir.
\end{abstract}

Anahtar Kelimeler: Türk kadını, İffet Halim (Oruz), Kadın Gazetesi, Türk basını, kadına yönelik süreli yayınlar

Makale Türü: Derleme

\begin{abstract}
The changes and transformations in education, culture and social fields paved the way for the raising of an educated class together with the beginning of the Turkish modernization process. Women can be seen to take part, albeit limited, within this group of intellectual. These pioneers who started working in the field of literature continued also in the field of women's movement and enabled important steps to be taken for the active participation of women in the public sphere. Iffet Halim Oruz has an important place among intellectual Turkish women as well. Her efforts both in the Turkish Women's Association and in the women publications are noteworthy. Women's publishing, which started with the Tanzimat period, showed a significant development in the process. However, a significant portion of these publications, which were prepared for women, were published in journal format and remained limited in content. For Women Newspaper, which was launched under the leadership of Iffet Halim Oruz on March 1, 1947 and has continued its publication life for a long time with its wide size, preferably including political and social issues along with broad content, broke an important new ground. This study aims to introduce İffet Halim Oruz, one of the Turkish intellectuals of the Republican era, and her works in Women Newspaper. Therefore, the writings of Iffet Halim Oruz, published in Women Newspaper between 1947 and 1963, on the subject on women's role in social, political and educational life were examined categorically.
\end{abstract}

\footnotetext{
* Bu makale, yazarın 2003 yılında Dokuz Eylül Üniversitesi Atatürk İlkeleri ve İnkılap Tarihi Enstitüsünde kabul edilen Türk Basınında Kadın Gazetesi'nin Yeri başlıklı yüksek lisans tezinden üretilmiştir.

${ }^{1}$ Pamukkale Üniversitesi, Fen Edebiyat Fakültesi, Tarih Bölümü, skarabulut@pau.edu.tr.
}

Atıf için (to cite): Karabulut, S. (2019). Bir Cumhuriyet Kadınını Yazılarından Tanımak: İffet Halim Oruz ve Kadın Gazetesi’ndeki Yazıları (1947-1963), Afyon Kocatepe Üniversitesi Sosyal Bilimler Dergisi, 21(3), 703-719. 
Keywords: Turkish Women, Iffet Halim (Oruz), Kadın Gazetesi, Turkish press, periodicals for women

Paper Type: Review

Giriş

Kadın Gazetesi, 2003 yılında Sezen Çoğun (Karabulut) tarafindan Dokuz Eylül Üniversitesi Atatürk İlkeleri ve İnk1lâp Tarihi Enstitüsü’nde Türk Basınında Kadın Gazetesi'nin Yeri başlığıyla yüksek lisans tezi olarak savunulduğundan bu yana çeşitli çalışmaların öznesi olmayı sürdürüyor. Bunlardan bir tanesi Birsen Ünal tarafindan 2010 yılında tamamlanmış Türk Kadınlığ İçin Çağdaş Bir Adım: Kadın Gazetesi (1947-1951) (Ünal, 2010) başlıklı yüksek lisans tezidir. Çalışma, Kadın Gazetesi ile ilgili detaylı bilgiler içermektedir. Ancak bu çalışma, çalışmanın merkezine İffet Halim Oruz'u ve onun Türk çağdaşlaşmasının önemli kadın figürlerinden bir tanesi oluşunu aldığı için Ünal'ın çalışmasından ayrılır. Çilem Tuğba Akdağ tarafından hazırlanan "Modernleşme Yolunda bir "Kadın Gazetesi" isimli makale (Akdağ, 2010) ise Kadın Gazetesi'ni çağdaşlaşma ekseni üzerinden incelemiş, böylece elinizdeki çalışmadan farklı bir anlatım içerisine girmiştir.

19. yüzyıl ile birlikte başlayan kadın sorunu günümüzde de popülaritesini sürdürmektedir. Çeşitli kadın dernekleri, basın kuruluşları bu konuda sürekli faaliyette bulunuyorlar. Gazete ve dergilerde çeşitli makale ve incelemelere rastlanıyor. Kadının, Türk toplumunda etkin bir rol oynamaya başlaması ve kadın haklarını savunan gazete ve dergilerin çıkarılması Osmanlı Devleti’nde Tanzimat dönemi ile birlikte yoğunluk kazanmıştır. Türk modernleşmesinin başlaması ile birlikte kadın hayatında da bir değişim göze çarpmaktadır. $\mathrm{Bu}$ değişimi Batıdaki gelişmeleri dikkate almadan anlamak mümkün değildir. Çünkü Batının etkisinin Osmanlı toplumuna yoğun olarak girdiği Tanzimat'tan itibaren, hemen her konuda olduğu gibi kadın meselesinde de Batının etkisi oldukça fazla hissedilmiştir.

Kadının statüsünün tartışma konusu olamaya başlaması Tanzimat dönemine rastlamaktadır. Her ne kadar Tanzimat Fermanı doğrudan kadınlara yönelik bir haktan bahsetmese de bu süreçte başlayan ve önceki dönemlere oranla önemli sayılabilecek ilerlemelere rastlanmıştır. 1856 Arazi Kanunnamesi, "kız evlatların babalarından kalan topraklar üzerinde erkek kardeşler gibi veraset hakkına sahip olmalarını" tanımakta, kölelik ve cariyeliği kaldırılmakta ve kadınlara sınırlı da olsa eğitimden yararlanma olanağı tanınmaktadır. 1842 yılında Avrupa'dan getirilen ebe kadınların Tıbbiyede verdikleri kurslarla başlayan, kadınlara eğitim ve özellikle mesleki eğitim verme çabası, 1858 'de ilk kız rüştiyelerinin, 1869 'da sanayi okullarının, 1870 'de Darülmuallimat yani kız öğretmen okullarının açılması ile devam etmiştir (Tekeli,1982: 195-198). Bu okulların yanı sıra, Osmanlı İmparatorluğunda bir düşünce basınının doğuşu da bu dönem de gerçekleşmiş ve Türklere Avrupa da neler olup bittiğini izleme ve Batının kültürel ve toplumsal olaylarının yankılarını görebilme olanağ sağlamıştır. Bu gelişmeye bağlı olarak kadının yükselmesi fikrini içeren yayınlar da basında yerini almıştır (Caporal, 1982: 51-54).

1908 'de II. Meşrutiyet'in ilanı kadınlara sosyal hayata katılma, çalışma hayatına girme ve yükseköğrenim görme gibi yeni bazı talepleri dile getirme imkânı sağlamış ve bu dönemde kadınların çıkardıkları dergi ve gazeteler çoğalmış, kadınlar pek çok dernekte faaliyet göstermiş, eğitim olanaklarından daha fazla yararlanmaya başlamışlardır. Kadın haklarıyla ilgili fikri gelişmeyi sağlayan yayınlar, kadınları çeşitli konularda bilinçlendirip, eğitmeyi amaçlamıştır. Eğitim, aile, çalışma, evlilik, çok eşlilik, sokağa çıkma, moda gibi konular dönemin gazete ve dergilerinde oldukça sık yer almıştır. Başlangıçta kadın haklarına gösterilen ilgi beklenenden az olmuşsa da, kadınlar arasında batılılaşma hareketleri arttıkça ve eğitim seviyesi yükseldikçe bu durum değişmiştir. Dönemin yayınlarında kadın meselesine eğilen ve bu mesele ile ilgili fikirler ileri süren kadın yazarlar ve yazılar artmıştır. Batı ülkelerindeki kadın haklarıyla ilgili gelişmeleri ve Osmanlı toplumundaki kadınların durumunu yazılarında dile getiren bu yazarlar, 
kadın haklarını savunmakta, bu konudaki hürriyet isteklerini bildiren edebi yazılar dikkat çekmektedir (Kaplan, 1998: 15-23).

19. yüzyılda Namık Kemal, Ahmet Mithat Efendi gibi Batıyı iyi tanıyan Osmanlı aydınları da kadın hareketini destekleyen yazılar kaleme almışlardır. 1913 yılında İstanbul'da yayınlanan Kadınlar Dünyası dergisi de ilk sayısında girişimlerini takdir eden erkek gazetecilere sayfalarında teşekkür eder ve yine aynı sayıda kadı hukuku sütununda Dr. Abdullah Cevdet'in davalarını savunduğunu belirtir (İnsel ve İlyasoğlu, 1984: s.163-164). Kadın sorununa olan ilginin artması, kadınların eğitim seviyesinin yükselmesine ve Meşrutiyet'in getirdiği özgürlük ortamı ile kadın yayınlarının çıkmasına zemin hazırlamıştır. Türkiye'de ilk kez kadınlık konusunda yayın yapan gazete Terakki'dir. 1868 yılında Ali Raşit ve Filip Efendi'nin çıkardıkları bu gazete sayfalarında kadın hak ve özgürlüklerini savunan yazılara yer vermekle kalmamış aynı yıl içinde haftada bir yayınlanan Muhadderat ismiyle bir de ek yayın çıkarmışlardır. Terraki'de ve Muhadderat'da sık sık işlenen konular arasında, kadınlara öğrenim hakkı tanınması, çalışma olanakları verilmesi, çok eşlilik ve kadın-erkek eşitliği yer almaktadır. İkinci olarak 1875'de Vakit gazetesi yazarları tarafindan Mürebbi Muhadderat adıla haftada bir kadınlıkla ilgili bir sayı çıkarılmaya başlanmıştır. Kadınlar tarafından çıkarılan ilk dergi ise Şüküfezar' dır. 1886'da Arife Hanım tarafından çıkarılan derginin bütün yazarları da kadınlardan oluşmaktadır. Arife Hanım derginin ilk sayısında yer alan önsözünde; “...Biz ki saçı uzun aklı kısa diye erkeklerin alaycı görüşlerine hedef olmuş bir tayfayız, bunun karşıtını ortaya koymaya çalışacă̆ız. Erkekliği kadınlığa, kadınlığı da erkekliğe üstün tutmadan çalışma ve iş görme yolunda yılmadan adımlarımızı atacağız..." (İnsel ve İlyasoğlu, 1984: 163-164) sözleri ile amaçlarını dile getirmiştir. 1895 yılında kadınlar tarafından çıkarılan bir diğer dergi ise Hanımlara Mahsus Gazete'dir. Sahipliğini Mehmet Tahir'in, yönetmenliğini ise karısı Şadiye Hanım'ın yaptığı haftalık dergi sayfalarında kadınların yazı ve şiirlerine yer vermiş, okuma yazmanın önemini vurgulamış ve üç prensibe hizmet ettiklerini belirtmiştir: iyi eş, iyi ana, iyi Müslüman olmak (İnsel ve İlyasoğlu, 1984: 164). Bunların yanı sıra İnsaniyet, Hanımlara Mahsus Gazete, Kadın, Demet, Mehasin, Kadınlar Dünyası, Hanımlar Âlemi, Kadınlar Âlemi, Musavver Kadın, Kadınlık, Türk Kadını, İnci gibi çok sayıda kadın dergisi yayın hayatında yer almıştır (Tansel, 1987: 300).

Meşrutiyetin ilk y1llarında görülen özgürlükçü ortam kadınlara yönelik gazete ve dergilerin yayınını hızlandırmış ve bu yıllarda yirmi civarında kadın gazete ve dergisi yayın hayatına başlamıştır. Tanzimat'la başlayan ve Meşrutiyet yönetimi ile hız kazanan kadın hareketinin edindiği bu tecrübeler, Cumhuriyet dönemi için önemli bir hazırlık süreci oluşturmuştur. Cumhuriyet'in ilanından önce de kadınlar, bağımsızlık mücadelesinin verildiği süreçte aktif rol oynamışlardır. Birinci Dünya Savaşı sonrası İtilaf Devletlerinin Anadolu topraklarında gerçekleştirdiği işgallere karşı düzenlenen protesto mitinglerinde yer almışlardır. İstanbul Darülfünun konferans salonunda yapılan konuşmalarda hanımlarda konuşmuşlardır. Ayrıca Sultanahmet, Üsküdar gibi mitinglerde de kadınlar konuşmuşlardır. Mitinglerde konuşan hanımların çoğu öğretmen veya darülfünun öğrencilerinden oluşmaktadır (Enginün, Canbur ve Özdemir, 1983: 14). Bu da Meşrutiyet döneminde açılan kız mekteplerinin, Milli Mücadeleye milliyetçi, aydın bir kadın potansiyeli hazırladığının göstergesidir. Ayrıca Milli Mücadele döneminde bir takım kadın cemiyetleri de kurulmuştur. Bu dönemde kurulan kadın cemiyetlerinin asıl amacı, vatanın kurtarılmasına hizmet etmektir. Bu amaçla yardım toplama, geniş kitleleri yardıma çağırma faaliyetlerinde bulunmuşlardır. Asri Kadınlar Cemiyeti ile Hilali Ahmer Kadın Kolları, özellikle askerlere giyecek temini ve ordunun sağlık hizmetlerinde çalışmışlardır. Türk Ocakları ve Muallimler Cemiyeti'nde çalışan kadınlar da mücadeleye katkıda bulunmuşlardır (Enginün, Canbur ve Özdemir,1983: 33).

Cumhuriyet döneminde kadın hakları konusunda ulaşılan seviye, bu devirlerdeki sosyal ve kültürel oluşumun doğal bir sonucu olarak görülmektedir. Meşrutiyet dönemi için uzak bir ideal gibi görünen bazı konular Cumhuriyet döneminde gerçekleşme firsatı bulmuştur. Avrupa'da o sırada en yeni kabul edilen ve en çağdaş sayılan medeni kanunlardan biri olan 
İsviçre Medeni Kanunu'nun Türkçeye çevirisi olan 1926 Kanunu, kadın hakları bakımından eskiye göre çok önemli bir adım niteliğindedir (Karabulut, 2012: 225-231). Çünkü bu yasa ile kadın nihayet hukuki bir kişilik kazanıyor; evlenme, boşanma, veraset, velayet gibi haklar açısından erkekle eşit bir statüye kavuşuyordu. Eskiye göre önemli bir adım olmakla birlikte, Medeni Kanun, kadın haklarının sınırlarını da çizmiştir. Kadınların siyasal haklarını kazanmalarının aşamalarına gelince: ilk aşamada kadınlar belediye seçimlerinde seçme ve seçilme haklarını elde etmişler (1930), ikinci aşamada ise (1934) milletvekili seçme ve seçilme hakkı kazanmışlardır (Tekeli, 1979: 380-381). Böylece kadınlar erkekler ile eşit siyasal haklara kavuşmuşlardır.

Cumhuriyet döneminde kadınlara sağlanmış olan haklar, kadının eğitim seviyesinin yükselmesi, kadının kamusal alandaki yerinin genişlemesi ile birlikte basında kadına yönelik gazete ve dergilerin sayısının da artmasını da sağlamıştır. Türk Kadın Yolu, Kadın Yazıları, Cumhuriyet Kadını, Ev-Iş, Kadın Dünyası, Türk Kadını, Hanımeli, Kadın Gazetesi bunlardan bazılarını oluşturmaktadır (İnsel ve İlyasoğlu, 1984: 172-176).

19. yüzyılda Batılı fikir akımlarının etkisi ile başlayan Türk modernleşme süreci önce Meşrutiyet daha sonra Cumhuriyet ile birlikte önemli bir değişim ve gelişim süreci yaşamıştır. $\mathrm{Bu}$ süreç içerisinde kadın yayınları ve kadın hakları konusunda da ciddi gelişmeler yaşanmıştır. 19. yüzyıl ile başlayan bu süreç Türk tarihinde önemli aydın kadınların yetişmesine zemin hazırlamıştır.

\section{Türk Modernleşmesinde Öne Çıkan Aydın Kadınlar}

Kadının gündelik hayat içerisindeki rolü, Tanzimat öncesinde sınırlı bir varlık gösterse de Tanzimat'tan itibaren bilhassa profesyonelleşme gerektiren bir takım iş kollarının neredeyse tümüyle kadınlara mahsus geliştiği söylenebilir. Mürebbiyelik, ebelik, hasta bakıcılığı gibi bazı meslekler kadınlara özgü nitelikleriyle gelişim göstermişlerdir. Bununla birlikte İkinci Meşrutiyet döneminden itibaren kadının gündelik hayattaki rolü daha görünür hale gelmiştir. Terzilik, fotoğrafçılık, memurluk, bankacılık gibi çok farklı ve bir kısmı son birkaç on yılda ortaya çıkan meslek dallarında boy göstermeye başlayan kadınlar böylece kamusal alan içerisindeki varlıklarını daha fazla hissettirir olmuşlardır (Erdem, Yiğit, 2010: 89-151).

Aydın Türk kadınının tarihsel süreçteki etkisi de yukarıdaki anlatıya uygun bir gelişim göstermiştir. Fikirsel etkinin yaygın aracı olan yazılı eserleri üretmek, Osmanlı Devleti'nde ancak aydın kesim ailelerine mensup kadınlara has bir özellik olarak görülmüştür. Olanakları görece geniş bu kadınlar, aldıkları eğitim ve yabancı dil bilgileri ile Tanzimat öncesinde, sınırlı da olsa Türk edebiyatında yer alabilmişlerdir. Ancak Tanzimat'la birlikte ortaya çıkan sosyal hareketlilik ve Batılı eğitim kurumları ile kadınlar, edebiyatın yanı sıra basın hayatına da girerek kamusal alanda varlıklarını hissettirmişlerdir (Bkz. Koç, 2018). Meşrutiyet döneminde kadınlara yönelik eğitim kurumlarının açılması ile birlikte eğitimli, yabancı dil bilen, meslek sahibi kadınların sayısı artmıştır. Görece yaşanan özgürlükçü ortamın da etkisi ile kadınlar toplum içindeki etki alanlarını genişleterek çevrelerini fikirsel olarak da etkilemeye başlamışlardır.

Dönemin önde gelen kadın yazarları arasında Ahmet Cevdet Paşa'nın kızı Fatma Aliye Hanımı görmekteyiz. Kendisi, 1895 yayın hayatına başlayan ve yazarlarının hemen hepsi kadın olan Hanımlara Mahsus Gazete başta olmak üzere, dönemin diğer dergilerindeki yazıları, çevirileri ve romanları ile tanınmıştır. Fatma Aliye, roman niteliğindeki ilk eseri olan Muhadarat'1 yayınladıktan sonra Refet, Udi, Levayih-i Hayat ve Enin'i kaleme almıştır. Yazar bu romanlarında dönemin kadınlıkla ilgili sorunlarına değinmiş ve kendisinin bu konudaki görüşlerini açıklama firsatı bulmuştur. Edebi dünya içerisinde yer almaya başladığı dönemden itibaren kadın erkek eşitliği, kadının eğitimi ve çalışması, evlenme şekilleri, çok eşlilik, boşanma, İslam da kadının yeri, sosyal hayatta aktif olma gibi konular yazarın eserlerinin konusu olmuştur (Karaca, 2011: 94-95). II. Meşrutiyet öncesinde edebi hayat içerisinde başlayan ve Cumhuriyet'e uzanan süreçte Fatma Aliye, kadın meselesi üzerine düşünen ve düşündüklerini roman ve çeşitli makalelerinde dile getiren öncü bir isim olanın yanında cemiyet 
faaliyetlerinde de aktif rol almıştır. 1897 Türk-Yunan Savaşı'nda şehit ve gazi ailelerine yardım amacıyla Cemiyet-i İmdadiye Derneğini kurarak yardım kampanyası başlatmıştır. Hilal-ı Ahmer Cemiyeti'nin ilk kadın mensubu olarak Trablusgarp ve Balkan Savaşı şehitlerine yardım faaliyetleri düzenlemiştir (Kanter, 2010: 22).

Ahmet Cevdet Paşa'nın ikinci kızı Emine Semiye Hanım da aydın kadınlar arasındaki öncü isimlerden biridir. 1864-1944 yılları arasında yaşamış, Batıda eğitim gören ilk Türk kadınıdır. Emine Semiye Hanım aynı zamanda Türk edebiyatının ilk kadın yazarlarından biri olmuştur. Hanımlara Mahsus Gazete, Kadın, Mütalaa, Inci, Yeni Gazete, Yeni Asır gibi çeşitli gazete ve dergilerde yazılar kaleme almıştır. Hanımlara Mahsus Gazete'nin çocuk terbiyesi hakkında yazılar yazan "Muharrire-i Mahsusa" unvanını almıştır (Kurnaz, 2008: 53-54). Yazarlığın yanı sıra siyasi hayatta da aktif rol oynayan Emine Semiye Hanım İttihat ve Terakki Cemiyeti'nin faal üyeleri arasında yer almış ve Selanik Kadınlar Şubesi'nin yönetiminde bulunmuştur. Daha sonra ise Osmanlı Demokrat Fırka'nın üyesi olmuştur. Emine Semiye'nin İkinci Meşrutiyet'in ilanı üzerine Hürriyet Meydanın da "yaşasın vatan, yaşasın millet, yaşasın hürriyet" (Çakır, 1996: 55) diye seslenerek verdiği nutuk da onun aydın bir kadın olarak demokrasiye olan inancının bir yorumu olarak değerlendirilebilir. İlk kadın derneği olarak kabul edilen Şevket-i Nisvan Cemiyeti'nin ve Edirne'de Hizmet-i Nisvan Cemiyeti'nin kurucusudur. $\mathrm{Bu}$ dernekler aracılığı ile kadınların eğitimine destek vermiş ve onları küçük işyerleri açarak üretime katılmaya teşvik etmiştir (Karaca, 2011: 128).

Şüphesiz Sabiha Sertel ismi de Türk kadın hareketinin ve aydın kadın tanımlamasının önemli öznelerinden bir tanesini oluşturmaktadır. Sabiha Hanım, Mütareke yıllarında yayınlanan Büyük Местиа' da kadın hakları alanında yazdı̆̆ yazılar ile sesini duyurmayı başarabilmiş ve Cumhuriyet Türkiye'sine değin etkileri görülecek önemli fikirleri kaleme almıştır. Örneğin 'Türk Feminizmi' teriminin ilk defa bu dergide işlendiği görülmüştür. (Toprak, 2014: 175).

Kadınların tarihsel süreçte boy göstermesi, Milli Mücadele yıllarında hayli belirgin hale gelmiştir. Milli Mücadele dönemi mitinglerinde kadınların aktif siyasette yer almaları, henüz kadınlara siyasi hakların tanınmadığı bir iklimde dikkate değer bir gelişmedir. Halide Edip Hanım'ın Fatih (Yeni Gazete, 20 Mayıs 1919), Kadıköy (Vakit, 23 Mayıs 1919) ve Sultanahmet mitinglerindeki konuşmaları (Alemdar, 24 Mayıs 1919), Şükûfe Nihal'in ikinci Sultanahmet Mitinginde yaptığı konuşma ve Üsküdar Doğancılar parkında bazı kadın göstericilerin işgali protesto için toplanmaları ve burada çeşitli nutukların atılması önemli örneklerdir (Alemdar, 19 Mayıs 1919). Ayrıca Milli Mücadele döneminde kurulan çeşitli kadın cemiyetlerinin de büyük yararlık gösterdiğini belirtmek gerekir. Bu cemiyetler 'Kasaba İslam Kadınları Cemiyeti', 'Anadolu Kadınları Müdafaa-i Vatan Cemiyeti' ve 'Müdafaa-i Hukuk Kadınlar Şubesi' olarak söylenebilir (Kurnaz, 1991:115-120).

Dönemin aydın kadınları arasında önemli bir isim de adını yukarıda da zikrettiğimiz Şükufe Nihal'dir. Şükufe Nihal birçok kadın dergisinde kadın haklarını savunan yazılar kaleme almasının yanı sıra çeşitli derneklerde de faaliyet göstermiştir. Milli Mücadeleyi desteklemek için Asri Kadınlar Cemiyeti'ne üye olmuş ve işgalleri protesto etmek amaciyla düzenlenen mitinglere destek vermiştir. Ayrıca Osmanlı kadınına eğitim haklarını kazandırmak, çalışma hayatıyla tanıştırmak ve kadın hakları konusunda bilgilendirmek amacıyla kurulan Müdafaa-i Hukuk-1 Nisvan Cemiyet'inde faaliyet göstermiştir. 1923 yılında da Kadınlar Halk Fırkasının çalışmalarında aktif olarak yer almıştır (Çalışkan ve Özey, 2016: 63).

Kadınların sadece kamusal alanda değil siyasal alanda da varlık göstermeleri gerektiği fikrini savunan Nezihe Muhiddin 1923 yılında Kadınlar Halk Fırkasını kurmuştur (Zihnioğlu, 2003: 127). 1924'de TBMM'de Hukuk-u Aile Kararnamesi gözden geçirileceği sırada Nezihe Muhiddin başkanlığında İstanbul da hanımlara mahsus konferans düzenlenmiş ve kadınlara boşanma, çok eşlilik ve erkekle eşit haklar konusunda bilgiler verilmiştir. Kendisi Kadınlar Halk Fırkasının kapatılmasının ardından Türk Kadınlar Birliği’nin kurucu üyeleri arasında yer 
almıştır. Ayrıca Kadın Yolu Mecmuası 'nda kadınların siyasi ve sosyal taleplerini içeren yazılar kaleme almıştır (Balcı ve Tuzak, 2017: 47).

Türk'ün Ateşle Imtihanı, Ateşten Gömlek gibi önemli eserleri ve Sultanahmet Mitinginde yaptığg çarpıcı konuşması ile ön plana çıkan Halide Edip de dönemin önemli bir diğer aydın Türk kadınıdır. Öyle ki, Birleşik Devletler'in ünlü gazetesi The New York Times sıkça Halide Edip Hanım'ın görüşlerine yer vermiştir (Koç, 2018: 306-322).Milli Mücadele sırasında Anadolu Ajansı ve Türk Ocaklarında faaliyet göstererek Milli Mücadeleye destek vermiştir.

20. yüzyılın başında edebi eserlerinde kadın konusuna sıç̧a yer veren önemli kadın yazarlardan biri de Müfide Ferit'tir. 1913 y1lında Hayat Hanım isimli hikâyesinde farklı toplumsal kesimlere mensup kadınların çalışma hayatının içinde yer alması gerektiği ve mutlaka bir meslek sahibi olmasının gerekliliği üzerinde durmuştur. Ayrıca Büyük Mecmua, Türk Kadını ve Hâkimiyet-i Milliye gibi çeşitli yayın organlarında makaleler kaleme almıştır (Demircioğlu, 1998: 13-15).

Türk aydınlanma süreci olarak tanımlanan bu dönemde birçok aydın Türk kadını yetişmiştir. Yukarıda dönemin öne çıkan birkaç aydın Türk kadınının faaliyetlerinden bahsedilmiştir. Bunların arasında öne çıkan bir başka isim ise İffet Halim'dir. Çalışmanın konusunu oluşturduğu için İffet Halim ve çalışmaları ayrı bir başlık altında değerlendirilmiştir.

\section{1. İffet Halim Oruz ve Çalışmaları}

Daha önce de değinildiği gibi bu dönemin aydın kadınları görece imkânları geniş, iyi eğitimli ailelere mensuptur. İffet Halim'de 1904 yılında Bağdat caddesinde bir köşkte, eğitimli bir ailenin çocuğu olarak dünyaya gelmiştir (Köse,2006: 2). İffet Halim, 1940 yılında İktisat Fakültesinden mezun olduktan sonra Fiyat Murakabe Teşkilatı'nda çalışmaya başlamış ve uzun yıllar burada görev yapmıştır (Oruz, 1986: 51). Fiyat Murakabe Teşkilatı'nda çalışırken diğer taraftan da Kadıköy Halkevi'nin kültür bölümünde başkanlık yapmıştır (Oruz,1986: 57). Daha sonra eşinin generalliğe yükselmesi üzerine kendisine görevinden ayrılması talebi gelmiş ve büyük istekle başladığı Fiyat Murakabe Teşkilatı'ndaki görevinden ayrılmıştır. Ancak işinden ayrılması onu kamusal alanda aktif ve üretken bir kadın olmasına engel olmamıştır. Gerek sosyal gerekse de siyasal alandaki çalışmalarına devam etmiştir. Özel Gazetecilik Lisesine öğretmen olarak atanmış ve burada basın tarihi, basın ahlakı ve basın tekniği gibi dersler okutmuştur (Oruz, 1986: 52).

Görüldüğü gibi İffet Halim, dönemin koşullarında yükseköğrenimini tamamlayan ilk kadınlardan biri olmuş ve çalışma hayatının içinde aktif olarak yer almıştır. Bu süre zarfında kadın hareketleri içerisinde de bulunmuştur. Bu konuda annesinin kendisi üzerinde yarattığ 1 etkiyi şu şekilde ifade etmektedir; "Ben annemin Hukuk-u Nisvan Cemiyeti'nde bulunmasından dolayı dokuz yaşından itibaren kadın hakları davasını benimsemişimdir. Ve bir ömrü bu davaya adamış bulunuyorum" (Oruz,1986: 12). Cumhuriyet' in ilk yıllarından itibaren aktif olarak kadın hareketinin içinde yer almıştır. Bu konudaki ilk filli girişimi ise 1927 yılında Türk Kadınlar Birliği'nin Diyarbakır şubesini açmasıdır (Oruz,1986: 25). Eşinin tayini dolayısıyla önce İstanbul'a daha sonrada Ankara'ya taşınmak zorunda kalmıştır. Ancak gerek kadın hareketindeki gerekse de sosyal alandaki çalışmalarına hiç ara vermemiştir. İstanbul'da bulunduğu sürede Türk Kadınlar Birliği'nin çalışmalarına destek vermiş, Ankara'ya taşındıktan sonra ise Halkevi ve Yardımseverler Derneği'nin çalışmalarına katılmıştır (Oruz,1986: 39).

İffet Halim Oruz'un çok yönlü kişiliğinin önemli göstergelerinden biri de edebiyat alanında verdiği eserleridir. Füsun, Tul Daireleri, Kışın Baharı isimli şiir kitapları; İstif̧̧i romanı ve yanı sıra Türkiye'de Kadın Devrimi, Yeni Türkiye'de Kadın isimli siyasi ve sosyal içerikli çalışmaları da kaleme almıştır (Köse,2006: 70-77). Bunların yanında İffet Halim Oruz'un kadın yayın hayatına kazandırdığı en önemli çalışması ise Kadın Gazetesi olmuştur. 


\section{Yöntem}

$\mathrm{Bu}$ çalışma, tarih bilimi alanında gerçekleştirilmiş olup, tarih metodolojisinin gereklerine göre inșa edilmiştir. Bu nedenle öncelikle konu tespiti gerçekleșmiş, ardından makalenin oluşturulabilmesi için gerekli olan birincil ve ikincil kaynaklar tespit edilmiştir. Sonrasında bu kaynakların elde edilmesi, kataloglanması ve değerlendirilmesi aşamaları gerçekleştirilmiştir. Birincil kaynak hususunda konunun öznesini oluşturan Kadın Gazetesi'nin ilgili nüshaları ve İffet Halim Oruz'un bu gazetede yayınlanan yazıları tespit edilmiştir. Bunlar, Kadın Gazetesi'nin süreli yayın koleksiyonuna sahip İzmir Milli Kütüphane'den temin edilmiştir. Ayrıca çalışmadaki bulguları ve savları destekleyip kanıtlayacak özelliklere sahip başka süreli yayınlardan da birincil kaynak olarak yararlanılmıştır. İkincil kaynak grubunu ise kitap, makale ve tezler oluşturmuştur. Başta çalışmanın gerçekleştirildiği Pamukkale Üniversitesi Kütüphanesi ve İzmir Milli Kütüphane olmak üzere çeşitli araştırma merkezlerinden bahse konu ikincil kaynaklar temin edilmiştir. Sonuçta, çalışmanın hipotez ve bulgularını destekleyecek birtakım bilgileri araştırma içerisinde okuyucuya sunacak veriler elde edilmiştir.

\section{3. İffet Halim Oruz'un Kadın Gazetesi'ndeki Yazıları (1947-1963)}

\section{1 İffet Halim Oruz Kadın Gazetesi'ni Anlatıyor}

Tanzimat ve Meşrutiyet döneminin sağladığı birikim ve Cumhuriyet yönetiminin kadınlara sağladığı olanaklar basında kadına yönelik yayınların sayısını arttırmıştır. 1925 yılında Türk Kadınlar Birliğinin yayın organı olarak Türk Kadın Yolu okuyucunun beğenisine sunulmuş 1926 'da ise Kadın Yazıları dergisi milli aile dergisi olarak yayın hayatına başlamış ve kadının aile içindeki işlevini yeniden tanımlamaya yönelik yazılar kaleme alınmıştır. Ayrıca derginin dikkat çeken yazılarından birinde Cumhuriyet yönetiminin Avrupa'ya öğrenci göndermesi eleştirilerek, bu yolla gençlerin ahlakının bozulduğundan bahsedilmiştir (Kadın Yazıları, I/7, Ekim 1962: 15). 1934'de çıkan Cumhuriyet Kadını dergisi Türk kadınını şöyle tanımlamaktadır; “...Cumhuriyet devrinde yaşayan kadın cepheli kadın değildir. Bütün manası ile iş hayatında olduğu kadar eğlenceli cemiyet hayatında da kendisini gösteren kadındır. Fikir mücadelelerine, edebiyat hareketlerine, spora ve aynı zamanda ev kadınlı̆̆ına, anneliğe ve zevceliğe merbut mükemmel bir kadındır..." (Cumhuriyet Kadını, I/1, Mart 1934: 5). İkinci Meşrutiyetten 1920'lere değin, kadın dergilerinde sıç̧a bahsedilen hedeflere, Cumhuriyet döneminin yasal düzenlemeleriyle ulaşılmıştır. Cumhuriyet Kadını dergisinde de tanımlandığ üzere, artık Türk kadını çok yönlü, iş hayatından toplumsal hayata, aile hayatından fikir hayatına kadar çok çeşitli alanlarda aktif bir birey haline gelmiştir. Ancak 1930'lardan itibaren kadın dergiciliğinin ana temalarını kadının annelik ve ev hanımlığı rolleri oluşturmuştur. Bu duruma örnek olarak 1937'de Tahsin Demiray tarafından çıkarılan $E v$-Işs dergisi gösterilebilir. Derginin çıkış amacı, Türk kadınına ev ve eş işleri ile ilgili bilgiler sunmak olarak açıklanmıştır (Ev-İs, I/1, Nisan 1937: 7-13). 1953 yılına kadar yayınını sürdüren dergi; örgü, yemek, dikiş, moda, güzellik ve görgü kuralları gibi konulara ağırlıklı olarak yer vermiştir. 1 Mart 1940'da moda ve sinema başlığı ile yayın hayatına giren Kadın Dünyası dergisi 1958 yılına kadar yayınına devam etmiştir. Çıkış amaçlarını şu sözler ile dile getirmişlerdir; “...ev, aile, çocuk, aşk, izdivaç, his, fikir, moda, süs, temizlik, güzellik, zarafet, cazibe, annelik, çocuk bakımı, ev idaresi... vesaire gibi konularda kadınlarımıza rehber....olacaktır..." (Kadın Dünyası, I/1, Mart 1940: 5-7). 1944 yılında aylık aile dergisi başlığı ile Türk Kadını dergisi yayına başlamış, ağırlıklı olarak çocuk bakımı gibi konulara yer vererek kadınları çocuk bakımı konusunda bilgilendirmeye çalışmıştır (Türk Kadını, I/4, Haziran 1944: 3-5). 1945 yılında "Ev-Iş-Moda, Elişleri, Yün; Örgü İşleri Dergisi” başlığı ile Ev-Kadın yayın hayatına başlamıştır. Yazı kurulu, derginin çıkış amacını şu sözlerle dile getirmiştir;

“...Şimdiye kadar yurdumuzda birçok kadın dergileri çıkmıştır. Fakat evi ve kadını temsil eden ve ciddiyetle bu işi başaracak dergiler bulunuyorsa da, bunlar kâfi derecede ev ve kadını tatmin edecek klymette değildir. Bugünkü 
modern Türk kızı, Türk kadını her şeyin daha iyisini ve daha üstününü elde etmek istiyor...Bugünün kadını, eskilere göre erkeğin yapamayacă̆ iş̧lerde bile yüksek zekaları ve bilgileri ile başaracak bir durumdadır. Fakat kadının ilk ve önemli vazifesinden birisi de ana olmaktır. Çünkü bir milletin, bir varlı̆̆ın yaşaması, gelişmesi ona bağlıdır. Ikkinci vazifesi de, sosyetede, ekonomide, aile geçiminde, ev bakımında ve evine yapabileceği büyük gösteriler her şeyden üstün tıtmasıdır..." (Ev-Kadın, I/1, Nisan 1945: 3).

1947'de Aile, 1948 yılında da Hanımeli dergileri kadın dergileri arasındaki yerlerini almışlardır. Hanımeli dergisi 1948-1953 yılları arasında yayın yapmıştır. Derginin Biz Bize adlı köşesinde kadının en önemli görevinin evini hem kendisi hem de eşi ve çocukları için yaşayabilecekleri temiz, toplu, samimi ve şirin bir yuva haline getirmek olduğu vurgulanmıştır (Babalık ve Erdoğan, 2016: 181). Yukarıda isimlerini verdiğimiz dergilerin çıkış amaçlarından da anlaşılacağı üzere kadınının çoğunlukla annelik, ev hanımlığı kimliğine vurgu yapılarak kadını dar anlamda değerlendirilen yayıncılık çizgisi izlenmiştir. Dergilerin konularını çoğunlukla moda, magazin, çocuk bakımı ve ev işleri gibi konular oluşturmuştur. Kadına siyasal, sosyal ve kamusal alanda aktif olarak yer veren rollerin yerine ev hayatı ile sinırlı roller biçilmiştir.

Ancak tüm bu kadın yayınları içerisinde hem biçim hem de içerik olarak farklı bir yere sahip olan,1 Mart 1947'de İffet Halim Oruz'un başkanlığında yayın hayatına başlayan Kadın Gazetesi olmuştur. Gazete; "Haftalık, İçtimai, Siyasi, Kadın Gazetesi”, Kadınlığımızın Düşünce, Görüş ve İsteklerine Hizmet Etmek İçin Çıkıyoruz", "Yuvayı Dişi Kuş Yapar - Yurdun İçtimai ve İktisadi Davaları, Kadın Elinin Çevikliğine ve Kadın Yüreğinin Hassaslığına Daima Muhtaçtır" sloganlarıyla yayın hayatına başlamış ve 1967 yılına kadar yirmi yıllık süreçte yayınını başarıyla devam ettirmiştir. Altı aylık süre zarfında Cumartesi günleri yayınlanan gazete, 18 Ağustos 1947'den itibaren Pazartesi günleri yayınlanmıştır. Ancak pazartesi günleri baskının yetişmesi konusunda yaşanan sıkıntılardan dolayı 13 Ekim 1952'den itibaren Perşembe günleri yayınlanmıştır. Gazetenin çıkış amacını kurucuları ilk sayısında şu şekilde açıklamışlardır:

"Cumhuriyet inkılâbı kadınlı̆̆ımıza ileri dünya kadınlı̆̆ arasındaki yerini vermiş bulunuyor. Türk kadınındaki kan ve ruh vasıflarını bu hamlenin hem hızla hem de başarı ile vücud bulmasını desteklemiştir. Bundan dolayı "Kadın Gazetesi" Türk kadınlığının geçmişteki mevzularıyla ilgilenmek istemeyecek, kısaca kadın-erkek eşitlik davası üzerinde fikir yürütmek lüzumunu duymayacaktır. Cemiyet içinde kadınla ilgili cinsel ve sosyal mevzular, 'Kadın Gazetesi'nin de mevzuunu teşkil eder. Memlekete ve aileye yararl görülen ve kadınlı̆̆ımızın tekâmülüne yardım edecek, ilim, sanat, fikir hareketlerine ve kadınla ilgili görüş, duyuş ve düşünceleri için "Kadın Gazetesi”"nin sayfaların daima kendisine açı bulacaktır. En tanınmış kadın yazarlarımız, kadın doktorlarımız, hukukçularımız ve terbiyecilerimizin fikir ve sanat hareketlerine sayfalarımızı vermiş bulunuyoruz. Okuyucu, kadınlı̆̆ımızın her türlü içtimai, edebi kabiliyetlerini ve sanat, fikir hareketlerini, ayrıca dünya kadınlık âleminden edinilecek bilgileri, derli toplu olarak 'Kadın Gazetesi'nde bulacaktır. Cemiyetin en büyük varliğını teşkil eden kadın tahassüsü ve şefkatinin kaynağl ve kucă̆l olmak amacımızdır. Yuvayı diş̧i kuş yapar-Yurdun içtimai, iktisadi ve kültürel davaları kadın elinin çevikliğine ve kadın yüreğinin hassasliğına daima muhtaçtır. Böylece kadınlı̆̆ımızın düşünce, görüş, duyuş ve isteklerine hizmet için çılkyoruz" (Kadın Gazetesi, 1 Mart 1947).

Görüldüğü gibi gazetenin amacı kadınlara, erkekler ile eşit haklar verilmesini talep etmek değildir. Çünkü bu haklar kadınlara Cumhuriyet inkılâbı ile birlikte verilmiştir. Fakat gazetede üzerinde durulan konu bu hakların fiiliyattaki geçerliliğidir. Bu konu da İffet Halim Oruz "Davalarımız" başlıklı yazısında şunları ifade etmiştir: 
"Biz davalarımızı siyasi, iktisadi ve içtimai olarak üç esasa bağllyoruz ve bu sıraya göre tahliline girişiyoruz. Vakı a ele aldiğımız mevzuların birbiri içine girmiş bulunması dolayısıyla ayırt edilmesi güçtür, bununla beraber izaha uğraşıyoruz... Türkiye'de, dünya ölçüsünde yapılmış olan siyasi kadın hamlesi, Meşrutiyet inkılâbında tamamıyla ele alınmış ve bunun neticesinde de kanunlaşmıştır. Yani eşit hak mevzuu, siyasi hakların eşitliğine kadar genişlemiş ve Türk kadınlığı buna da sahip olmuştur. Kadınlarımız arasında da eşit hak vermeyen maddeler, teferruata aittir denecek kadar ehemmiyetsizdir. Belde, aile birliği meselelerinde gördüğ̈̈müz gibi sosyal bünyenin icabı bakımından ele alınmış ve disiplin esaslarına dayanır, eşit hak mefhumu ile ilgili olmayacak bir takım şeylerdir. Herhalde siyasi eşitlikte, nazari olarak tam bir olgunluk vardir. Fakat fiili olarak bu olgunluğumuz tamamıyla mevcut mudur?...ISste bir dava... Ikinci olarak iktisadi davalarımız vardır ve bununla ilgili meseleler ortaya çıkar. Kadının çalışması memleketin bünyesi icabına uygun mudur? Vakıalar nelerdir?...Üçüncü olarak, içtimai davalar vardır. Kadınlığımız, İslam akidelerinin yarattı̆̆ aile kadını tipinden ayrılmıştır. Bilhassa, şehirde, garpl kadın tipi dediğimiz şeklin kisvesine ve adetlerine bürünmüş̧ür. Ancak bu şekilde içinde en mükemmel, en orijinal vasfi edinmiş midir? Yoksa gelenekleri bırakarak, görenekleri arasında bocalamakta midır? Aile bütçesine bir yük mü olur? Çocuğu yetiştirmede eksik tarafları var mıdır" (Oruz, Kadin Gazetesi, 22 Mart 1947).

Anlaşıldığı üzere, gazetenin amacı, kadını sosyal hayatta daha aktif kılmaktır. Sahip olduğu hakların farkında olarak bu haklarını olgunlukla sosyal hayatta kullanmasını sağlamaktır. Aynı zamanda kadının bir ülkenin iktisadi bünyesindeki önemi vurgulanarak, kadınları çalışma hayatına sevk etmektir. Buradan da Kadın Gazetesi'nin dönemindeki kadın gazete ve dergilerinden ne kadar farklı olduğu görebilir. Öncelikle ebat olarak Kadın Gazetesi bir dergi gibi küçük boyutlu ve kadın resimleri ile süslü olarak değil, bir gazete gibi büyük ebatta yayınlandığı belirtilmelidir. İçerik olarak da kadını sadece bir anne veya ev kadını olarak görmektense sosyal hayatın bir parçası olarak görmüş̧ür. Bu konuda İffet Halim Oruz "Kadın Gazetesi 'nin Bir Yıllık Çalışması Dolayısılyla” adını taşıyan makalesinde şunları yazmıştır:

"Memlekette yokluğumu hissettiğimiz için giriştiğimiz bu mücadelenin birinci yılını tamamlamış oluyoruz. Kadınlar Dünyası adını taşıyan ve 1914'den sonra bir adım daha Türkiye'de benzerine rastlamadı̆̆ımız derginin çıkış ylllarından bugüne kadar aradan 34 yll gibi uzun bir devre geçmiş bulunuyor. Bu otuz dört yılın bizim tarihimize göre süresi bir asır kadar uzundur. Çünkü hadiseler o kadar değişik, geçirdiğimiz inkılâbın yürüyüss kabiliyeti o kadar hamlelidir. Kadınlarımızda bu hamleler içinde o derece geniş hamlelerle yürümüş̧ür ki memleket ölçüsü içindeki yerini almıştır. Fakat buna rağmen teşkilatsız ve kendi kendimizin dayandiğ ortasında ve 1948 yılında kadınlığına seçme hakk tanınmış ve tek dereceli seçim ölçüleri onanmış bir millet kadrosu içinde bulunarak düşünüyoruz ki; cinsiyetimizin hususiyetlerini gözeterek, yurtta, ailede, dernek işlerinde ve meslek sahasında kadınlı̆̆ımızın vatana ve millete daha yararlı olması için gücünü kendi zümresinden olan topluluklara ve yine mahiyetteki içtimai ve fikri mücadelelere ön ayak olacak yayın kabiliyetine son derece ihtiyact vardır...Çıkış tarihimiz olan 1 Mart 1947 gününden beri mücadelemizin başlıca hedef noktalarl şunlardir:

1. Gazeteye bir kapak ve kapağın üzerine açık saçık bir kadın portresi yapıştırmamak için bayilerle mücadele ediyoruz. 
2. Ecnebi gazeteleri ellerinde dolaştırmak zevkinde ve bu yüksek teknik kabiliyetli mecmualardan aşağısını beğenmemek illetiyle malul olan zümrelere dertlerimizi ve davalarımızı dinletememekle mücadele diyoruz.

3. Adamsendecilikle mücadele ediyoruz.

4. Tamamıyla kendilerine hitap ettiğimiz halde böyle ă̆ır başlı şeyleri okumayan büyük bir zümre ile mücadele ediyoruz..." (Oruz, Kadın Gazetesi, 1 Mart 1948).

İlk çıktığ1 günden itibaren mücadelesini sürdüren gazete, zengin bir içerikle siyasal, toplumsal ve ekonomik konulara değinmiştir. Aynı zamanda kadınlar için moda sayfası, sinema, tiyatro, edebiyat köşelerine de yer vermiştir. Bunların yanı sıra kadınının toplumdaki aktif rolünün öneminin anlaşılması sağlamak için "Dünya Kadınlığ ”" başlıklı bir köşe hazırlanarak tarih içerisinde, ülkelerinin toplumsal, siyasi, ekonomik ve eğitim alanlarında ismini duyurmuş başarılı kadınlardan örnekler verilmiștir. Gazete bu yazılar aracılığıyla Türk kadınının toplum içerisindeki rolünü daha faal bir duruma getirmeyi ve Türk kadınına verilmiş olan hakların sadece resmiyette kalmayarak fiiliyata dökülmesini amaç edinmiş ve bu doğrultuda birçok farklı konuyu sütunlarında işlemiştir. Bu konuyu İffet Halim Oruz "Kadın Gazetesi” " başlıklı yazısında şu şekilde açıklamıştır;

"Bu sayldan itibaren içtimai, iktisadi, edebi, kültürel mevzularla beraber, kadın ve çocuk să̆lı̆̆l, zarif ve ucuz giyinme, zevkle ev döşeme, çiçek bakımı, hayvan sevgisi, spor, dünya kadınlığ l, köy kadınlı̆̆l, ev kadını mevzularından bahseden sütun ve sayfalar açmaya başlamıştır. Sütunlarımız memleketin her tarafindan gönderilen kadınlık düşünce, dert ve davalarına açık bulunacaktır. Cemiyetimiz içindeki kadinlık hareketlerini, hassasiyetle takip etmekteyiz. Bu suretle okuyucularımız, Kadın Gazetesi'nde kadınlığımız hareketlerini bulabilecekler... Dünya kadınlı̆̆ hakkında da daima bilgi vereceğiz. Gelecek sayılarımızda meslek, aile, köy kadınlarımızla yapılmış anketler ve röportajlarda bulunacaktır... Aile kadınlarımıza kolaylık olmak üzere patron şemaları neşredeceğimiz gibi aynı zamanda patronda vereceğiz... Avrupa moda evleri ile yapılacak hususi temaslar ile yabancı basin ve gazete mecmualarında yayınlanmamıs orijinal modellerde temin olunacaktır. Elişlerine, trikotaja da ayrıca yer vereceğiz. Bu suretle Kadın Gazetesi her bakımdan kadınlığımıza yardım ve hizmet edecektir" (Oruz, Kadın Gazetesi, 1 Mart 1947).

Gazete bazı sayılarını tematik basarak, o sayıyı yalnızca bir konuya ayırmıştır. Örneğin 12 Temmuz 1947 tarihinde çıkarılan sayı 'moda' mevzusuna hasredilmiş ve bu durum "Moda ve Lüks" başlıklı yazısında İffet Halim Hanım tarafından şöyle açıklanmıştır;

Kadin Gazetesi, bu sayısinı moda mevzuuna hasretti. Sosyal davalar ve dertler üzerinde kadınlığımızın görüş, düşünce ve duyuşlarına sayfalarını açmış olan gazetemizin, bütün bir kadınlık âlemini pek yakından ilgilendiren ve iyiye kötüye çekilmeye pek müsait olan mevzuu ile etraflica uğraşmast yerinde olacaktır...” (Oruz, Kadın Gazetesi, 12 Temmuz 1947).

1947 yılında yayın hayatına başlayan Kadın Gazetesi, amaç ve ilkelerinden taviz vermeyen özellikleriyle 1962 yılına kadar gelmeyi başarmıştır. Fakat 10 Mart 1962 tarihli sayısından itibaren sadece Kadın olarak kalmış, siyasi konulara dair içeriği zayıflayan ve görsellere ağırlık veren bir dergi özelliğine bürünmüştür. Hâlbuki çıktığ 1 yıllarda diğer kadın yayınlarının kapaklarını kadın resmi ile süslemelerini eleştirmiştir. Fakat bu yıldan itibaren Kadın Gazetesi de kapağını bir kadın resmiyle süslemiş ve bu durumu gazetenin sahibi İffet Halim Oruz şu şekilde açıklamıştır:

"Kadınlar, Cumhuriyet'in nimetlerinden kültürel alanda gereği kadar faydalanmışlardı da, bu gücü teşkilatlı olarak kullanmasını bilememişlerdir. Devrimci geçinen bütün partilerin idarecileri ise asla kadın devrimine yer 
vermemişlerdir. Bu noktada dava toplumun görüşüne dayanır. Onunla aydın kadın teşkilatlı olarak savaşacaktır. Kadın Gazetesi bu savaşımın organıdır. Doğrusu şunu da belirtmeliyim ki, son yıllarda aydın kadının bizim çevremizdeki halkalanması gücümüzü arttırmıştır. Birçokları da, çok okunması Kadın Gazetesi'nin yaldızlı hap gibi, umumi efkârı tutan ölçülerle yayınlanmasını deyimler. Bu sayıda kapağımıza dikkat edenler, adeta arkadaşlar arasında savaşma açan bir yaldızlı hapla çıktığımızı göreceklerdir. Bu bir deneydir, bizi davalarımızdan şaşırtmaz..." (Kadın Gazetesi, 10 Mart 1962).

Oruz'un açıklamasından da anlaşıldığı gibi gazetenin içeriğinde çok fazla değişiklik yapma yoluna gidilmemiştir. Ancak ebat olarak küçüldüğü için siyasi içerikli haber sayısında azalma olmuş buna rağmen sosyal konular ve fikir yazılarında herhangi bir daralma olmamıştır. Oruz bu konu ile ilgili şunları söylemektedir;

"Kadın Gazetesi, 1 Mart 1963 tarihinde 17. yayın yllina girmektedir. Dergi haline girdiğimiz 1 Mart 1962'den bu yana da bir yll geçmiştir. Her yıl dönümünde baş sütunumuzda davalarımız, hamlelerimiz ve karşılaştığımız birçok güçlükler hakkında çeşitli yazılar kaleme aldık. Şaşmaz ilkemiz Atatürk kadın devrimleri konusunda da meselelerimizi anlattı... Türkiye'deki bütün kadın yazarlara bir çağrı göndererek, bizi desteklemelerini istedik... Bu hareketin sonunda pek ala bir kadın yazarlar kurulması da mümkündür. İşte Kadın Gazetesi'nin 16. yılını kapatırken giriştiği son hamle budur..." (Oruz, Kadin Gazetesi, 4 Mart 1963).

Gazetede, her ne kadar biçimsel olarak bir değişiklik yaşanmış olsa da kadının kamusal alanda aktif etkisini kaybetmemesi için Türk kadınını bilinçlendirebilmek amacıyla sosyal içerikli yazılar yayınlanmaya devam etmiştir.

\subsection{Siyasal Hayat ve İffet Halim Oruz'un Kadın Gazetesi'ndeki Yazıları}

Daha önce de değinildiği gibi Kadın Gazetesi, diğer kadın gazete ve dergileri gibi moda, magazin haberlerinden ziyade sosyal, ekonomik ve eğitim konularına öncelik vermiştir. Tüm bunların yanında Cumhuriyet kadınının daha bilinçli bir vatandaş olabilmesi ve demokrasinin gereği olarak yönetime katılabilmesini sağlamak amacıyla siyasi konulara da önemli ölçüde yer ayırmıştır. Özellikle demokrasi ve demokratikleşme süreci, var olan kadın hakları ve kadının siyasal hayat içerisindeki önemli rolü üzerinde durulmuştur. Ülkenin demokratikleşme süreci içerisinde bulunduğu çok partili hayata geçiş döneminde, gazete bu konuya duyarlı davranarak önemli yazılar yayınlamış ve bu konuda kadınlara düşen görevlerden bahsetmiştir. İffet Halim Oruz bu konuyu "Yeniden Seçim Yapılırsa" başlıklı yazısında şu şekilde ifade etmiştir;

"İ̧ politika olayları devam ede gelmektedir. Bu arada, son günlerde yeniden seçim yapılacă̆ rivayet olunmaktadır... Bugün üzerinde duracağımız konu mücerret olarak seçim olayının kadınlarımız ile ilgisi ve kadınlarımızın seçimde oynayacă̆ı roldür. Günden güne demokratik bir inkişafa doğru gittiğimize, tek parti yerine çok partili siyasi durumumuz olduğuna göre, vatandaşların yarısını teşkil eden kadınların nasıl bir siyasi rol oynayacă̆ına izaha bilmem lüzum var mı? Bizim asıl üzerinde durmak istediğimiz nokta bu rolü olgun ve ă̆ır başlı olarak oynayabilmektir. Bu ă̆ır başlılıktan kasıt nedir? Bir kere onu açıklamaliyız. Bizim gibi yakın tarihte inkılâp geçirmiş ve hala da bu inkılabı olgunlaştırmaya çalışan bir millet için ilk onarılacak şey, medeni bir hak olan seçme ve seçilme hakkının vatandaş tarafindan kullanılmasıdır. Bilindiği gibi kültür seviyesi olgunlaşmış memleketlerin vatandaşı mutlaka bu hakkı kullanır ve kullanmayı bir vatan görevi bilir. Çünkü onu kullanmakla millet işlerinin gidişine kendi isteği ve düşüncesi de katılmış olur. İkinci olarak aranan vasif, hakkin konulmasinda gereken vicdan kanaatini rey pusulasinı 
atan vatandaşta mevcut inkişafi tam ve mükemmeldir. Buna göre memleketimizde reye iştirak hakkına erkeği gibi yetkili bulunan kadınlarımızdan beklediğimiz, birinci olarak adamsendecilik yapmaması, ikinci olarak da vicdan kanaati rey pusulasını atmasıdır... Kadın seçme hakkını kullanmada kâmil bir vatandaş rolü oynamalıdır...” (Oruz, Kadın Gazetesi, 6 Ekim 1947).

$\mathrm{Bu}$ yazıdan da anlaşıldığı gibi Türkiye'nin içinde bulunduğu bu önemli süreçte kadınların üzerine düşen görevleri layıkıyla yerine getirmeleri beklenmiştir. Bu konuda görevini tam anlamıyla yerine getirmemiş olan İstanbul kadınına şöyle bir eleştiri getirilmiştir; "Sekiz yüz bine yakın nüfusu bulunan ve yarlsından fazlası da kadın vatandaşı olan İstanbul'da 1946 seçimlerine Türk kadınlı̆̆l kendi temsilcisini seçememiştir... Kısmi seçimlerde İstanbul

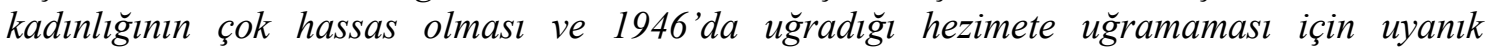
bulunmasinı tavsiye ederiz" (Kadın Gazetesi, 29 Haziran 1948).

Oruz, demokratikleşme sürecinde kadınları bilinçlendirmek için çeşitli sayılarda yazılar yazmaya devam etmiştir. Kadınlara bu süreçte ki sorumluluklarını "1950 Seçimlerinde Kadınlarımıza Düşen Görev" başlıklı yazısında şu şekilde kaleme almıştır; "CHP Meclis Grubu 24 Mart Cuma günü seçimin yenilenmesine karar verilmesine tasvip etmiş bulunuyor....5545 nolu Milletvekili Seçim Kanunu ile 1950 yll seçim devresine giren Türkiye, demokrasi inkılabının yeni sınavın vermiş olacaktır. Bu suretle milletin har ferdine olduğu kadar, zümrelerine ve teşkilatı olan kurullarına büyük ve milli bir vazife düşmektedir...1934 yılından beri seçme ve seçilme hakkını kazanmış olan kadınlarımız da bu suretle medeni haklarını kullanma durumundadırlar..." (Oruz, Kadın Gazetesi, 27 Mart 1950).

Türk kadını, gelişmekte olan diğer ülkelerin, özellikle de İslam ülkelerinin kadınlarıyla karşılaş̧tırıldığında, önemli politik ve sivil haklara sahiptir. Türkiye'de daha 1920'lerde kendi eşlerini seçme, boşanma davası açma ve çocuklarının velayetini isteme gibi siyasal haklara kavuşmuş olan kadınlar için 1923 yılında ücretsiz eğitim alma zorunluluğu da getirilmiştir. Kadınlara 1930 yılında yerel seçimlerde, 1934 yılında genel seçimlerde seçme ve seçilme hakkı tanınmıştır. Bu haklar bütün kadın nüfus tarafından eşit düzeyde kullanılmasa da, birçok kadın eğitim, siyasal katılım ve istihdam fırsatı elde etmiş, sanayileşmiş ülke kadınlarınkine benzer haklar kazanmıştır (Arat, 1998: 51).

Cumhuriyet yönetiminin kadınlara tanımış olduğu bu hakları Oruz "Cumhuriyet Kadını" başlıklı yazısında şu şekilde ifade etmiştir;

“...Eskinin kötüsü kadar varsa tabii açılkayacă̆ız ve pek tabii Cumhuriyet devrinde yapılıp edilenleri döküp saçacağız. Çünkü biz samimi olarak bu rejime bağglyyz ve görünen köye kllavuz istemeyeceğine göre Cumhuriyet rejiminin kadınlığımıza hak ve hürriyet adına çok şeyler getirdiğine şüphe etmiyoruz. Yoksa medeni hukuk sahasında, evlenme, boşanma ve verasette eşitlik hakkını bu devirde kazanmadık mı? Eşit vatandaş olma bakımından belediye ve Millet Meclisi seçiminde dünyanın en üstün ölçülerine uyan bir mertebeye bu devirde ulaşmadık mı?...IŞ hayatının her sahasında her türlü içtimai mesleğe eski tabiri ile sülük etme hakkını bu devirde almadık mı?...Evet bunların hepsi oldu. Bu 23 sene içinde kazanıldı..." (Oruz, Kadın Gazetesi, 17 Kasim 1947).

Atatürk'ten sonra cumhuriyet mirasını devralan İsmet İnönü, Kadın Gazetesi'nin yazarları tarafindan Atatürk devrimlerinin koruyucusu olarak görülmüş ve Oruz İnönü'ye duyduğu saygıyı şu sözler ile dile getirmiştir;

“...Türk kanunlarında kadın haklarını geriletici yeni hiçbir hüküm yoktur. Her türlü eşit hakları vardır. İnönü, Atatürk'ün en yakın inkılâp arkadaşılır ve bu inkılabı onunla beraber geliştiren şahsiyettir ve bu role devam etmektedir. Siz, değerli bir inkılap büyüğü ve şahsiyeti olan Sayın Devlet 


\section{Başkanı İsmet İnönü ise; bizim en kuvvetli dayană̆ımızdır...." (Oruz, Kadın} Gazetesi, 7 Kasim 1949).

Gazete siyasal konularda sadece kadın haklarının savunulmasına yer vermemiş bunun yanında ülke içinde yaşanan günlük siyasal olaylar da gazetenin sayfalarında yer almıştır. Bu süreçte Demokrat Parti’nin kuruluşu demokratikleşme yolunda önemli bir gelişme olarak değerlendirilmiş ancak 1950 yılından itibaren iktidarda bulunan Demokrat Parti'nin izlemiş olduğu bazı politikalar gazetenin eleştirisine uğramıştır. Örneğin Oruz "Din ve Dil Meselelerine Dair” başlıklı yazısında “...Arapça ezan okunmasının bir ceza müeyyidesine bă̆lanması, hakikaten layizme uymaz bir işti ama, devlete bağlı bir teşekkül olan Diyanet İşleri Reisliğinin Arapça Ezan okunmasını tamim etmesi, laik prensibe uyar mı? Ve güzel Türkçemizle iman ehlini çağırmanın ortadan kaldırması, bizim gidişimize uyar mı?..."(Oruz, Kadın Gazetesi, 17 Temmuz 1950) ifadeleri ile ezanın dilinin değiştirilmesi ve tekrar Arapça okunmasını eleştirmiştir.

\subsection{Sosyal-Eğitim Hayatı ve İffet Halim Oruz'un Kadın Gazetesi’ndeki Yazıları}

Kadın Gazetesi Türk kadınını birçok konuda bilgilendirebilmek amacıyla çeşitli alanlarda yazılar kaleme almıştır. Özellikle kadının sosyal hayattaki yeri ve önemi üzerinde durularak, kadını bir birey olarak toplum içerisinde daha aktif kılmayı hedeflemiştir. Bu hedef doğrultusunda sosyal hayatta gelişen olaylar konusunda da kadınlara bilgiler sunulmuş ve kadınların sosyal hayattaki faaliyetlerine önemli yer ayrılmıştır. Bu dönemde bir takım kadın örgütlerinin çalışmaları gazetenin sayfalarında yer almıştır. 13 Nisan 1949'da kurulan Türk Kadınlar Birliği'nin kuruluşuna Oruz gazetede ki şu yazısı ile destek vermiştir; “...memlekette bir kadın teşekkülüne ihtiyaç vardır. Fakat geriye dönerek süfrajetlik'ªpmak için değil, tabir yerinde ise; misyonerlik yapıp kadınlığımızı ve geri kalan Orta Şark kadınlığını yetiştirmek için" (Oruz, Kadın Gazetesi, 5 Nisan 1947). Birliğin kuruluş amacını da Oruz "Türk Kadın Birliği" başlıklı yazısında şu şekilde ifade etmiştir;

“....Türk kadın inkalabinın bir gerileme hareketi göstermemesi için korunmasına lüzum hasıl olmuştur. Binaenaleyh partiler siyaseti dışında ve en tabii olarak kadın unsur tarafindan bu korunmanın yapılması lüzumludur. Kadın, Türk demokrasisinde hak, vazife ve mesuliyet anlaylşının inkişafina hizmet etmelidir. Demokratik rejimi yıllardan beri benimsemiş ve kadınlarina eşit vatandaşlık hakkını olan memleketlerde de bu kadın teşekkülleri vardır. Onlar da bir taraftan hakların korunması diğer taraftan kadınlık alemindeki feci manevi yaraların önüne geçilmesi için faaliyet gösterirler. Buna göre Türk kadınları da kendi meseleleri ile bizzat meşgul olmalıdırlar. Bundan başka kadının kendi hususiyetine göre çeşitli mevzulardaki faydalı rolünün sağlanması için kadınlar varlık göstermelidir. Hülasa, partiler siyasetine dayanmadan kadinların önce kendilerine dayanması, hakların savunmasl, çalışması hususiyetlerinden cemiyeti faydalandırması gerekir... "(Oruz, Kadın Gazetesi, 16 May1s 1949).

Ayrıca Türk Kadınlar Birliğinin çalışmalarına daha sonra ki sayılarda da genişçe yer verilmiştir.

Eğitimin toplumun temelini oluşturduğuna inanan gazete yazarları, bu konuya yoğun olarak ilgi duymuşlardır. Çocuk ve kadın eğitimi, eğitimdeki aksaklıklar ve bunların çareleri üzerine yazılar yayınlamışlardır. Gazetenin yazarları bizzat kendileri de eğitim toplantıları düzenleyerek, problemleri düzeltebilmek için Milli Eğitim Bakanlığına yardımda bulunmaya çalışmışlardır.

\footnotetext{
${ }^{2}$ Süfrajetlik kavramı; 20. yüzyılın başlarında Birleşik Krallık, Fransa ve ABD gibi dönemin en gelişmiş kapitalist ülkelerinde, pasif direniş, kamu toplantılarını bölme, açlık grevi yapma gibi yollarla kadınların seçme ve seçilme hakkını savunan, az çok organize olmuş radikal kadın hakları savunucuları için kullanılan tanımlamadır. Süfrajet hareketi, ağırlıklı olarak orta sınıftan gelen kadınlar tarafından yürütülmüştür (Tekeli, 1988: 34).
} 
Kadın Gazetesi ilk eğitim toplantısını 1949 yılında yapmış ve gerçekleşen çalışmalar konusunda Oruz şu bilgileri vermiş̦tir; "Kadın Gazetesi 1949 yllı çalı̧̧malarının ilk adımını eğitim davası hamlesi ile atmuştır. İki yıldan beri yazarlarımızın ele aldığı bu mevzuu Ocak ayı başından itibaren bir hareket haline geçirmekle daha disiplinli ve planlı olarak çalışacağımıza inanıyoruz...Milli Ĕ̆itim Bakanlı̆̆ımızda terbiye problemleri üzerinde hamleli bir program hazırlanırken Kadın Gazetesi, annelerin bu davayı birinci planda ele alması iş̧i üzerinde durmuştur..." (Oruz, Kadın Gazetesi, 10 Ocak 1949). Bu toplantıya milli eğitim ailesine mensup profesörler, doktorlar, terbiyeciler ve tanınmış aile kadınları katılmıştır.

İffet Halim Oruz, "Eğitim Projesi” başlıklı yazısında Milli Eğitim Bakanlığı'nın bir genelgesini şu şekilde değerlendirmiştir;

"Bu yazımda Milli Ĕ̈itim Bakanlı̆̆ının 22.9.1948 tarihli genelgesi üzerinde durmak istiyorum. Ortaokul ve lise programlartyla bu kurumlara ögretmen yetiştirme işlerini ve demokratik eğitim problemini gözden geçirmek maksadiyla toplanan komisyonun raporu mahiyetinde bulunan bu genelge hakikaten üzerinde durulmaya değer! Zira Milli Ĕ̈itim bir bütün halinde göz önünde tutan, yani çocuğu doğdŭ̆u andan üniversite sıralarına varıncaya kadar kavrayan bu görüş tarzı şimdiye kadar yer yer ve kisım kısım ele alınmış olan bir takım eğitim meselelerini birbirine bağlamak suretiyle müteselsil ve ahenkli bir çalışmayl sağlamak gayesindedir. Rapor bir taraftan lise ve orta okullar programın ve bu okullara öğretmen yetişstirme işini ele almakta, diğer taraftan da, okul öncesi çocuklarının eğitimi ile, okul çocuklarının eğitimi göz önünde tutmaktadır....Memlekette böyle bir ĕgitim programı tatbik edilince, aileden başlamak üzere bütün Türk cemiyetine şümulü olan yeni bir anlayış devresinin açılması gerektiğini işaret etmek isterim..."(Oruz, Kadın Gazetesi, 13 Aralık 1948).

Eğitim konusunda da özellikle kadınların ve kız çocuklarının eğitiminin toplumun gelişmesinde oynadığı rolün önemini anlatan yazılara yer verilmiştir. Kadınların ve kız çocuklarının eğitimi Atatürk döneminde de önemsenmiş ve bu doğrultuda çeşitli kurumlar açılmıştır. Bu kurumlardan bir tanesi de Kız Enstitüleri'dir. Bu kurumun önemini Oruz şu şekilde ifade etmiştir;

“...Yalnız genç kızlarımızı yetiştirmekle kalmayıp, bütün Türk kadınlığına kucak açmış bulunan enstitüler hakikaten becerikli ve kuvrak elli bir aile kadınliğı unsuru meydana getirmiştir. Şapkacılık, pastırmacılık, çiçekçilik gibi küçük el sanatlarına varıncaya kadar kadınlarımızı yetiştiren bu okullar, biçki, dikişi, leke temizleme vb. ev işlerinde de geniş zümreyi bilgili ve becerikli etmiştir. Bundan sonrada, bahsettiğimiz el sanatları için müstahsil bir zümre meydana getirerek Türk kizlarına böyle bir çalışma imkânı yaramıştır. Türk kadınlığı hakikaten açılan çı̆̆ırdan faydalanmıştır. Bu faydalanmayı en çoğa götürmek için ne mümkünse yapalım...” (Oruz, Kadın Gazetesi, 14Haziran 1948).

Kadınların eğitim hayatının içinde yer almalarının desteklenmesinin yanı sıra çalışma hayatının içinde yer alması da Kadın Gazetesi'nin yazarları tarafından desteklenmiştir. Kadınların çalışmasının toplumun ilerlemesinde önemli role sahip olduğunu Oruz şu cümleler ile ifade etmiştir; “...Bir memleketin çalışkan kadınlığı, tarla sürüyor, yün eğiriyor, süt săgıyor, eve bakıyor ve daha birçok şeyler... Biz bu unsurun işlemesine bakmallyız" (Oruz, Kadın Gazetesi, 26 Ocak 1948).

\section{Sonuç ve Öneriler}

Türk kadın haklarının bugün ulaşmış olduğu nokta, uzun tarihsel süreç içinde verilmiş mücadeleler sonunda olmuştur. 18. yüzyıla gelindiğinde Batı dünyasındaki kadın, eğitim konusunda bazı haklar elde etmiş ve sosyal hayata dâhil olmaya başlamıştır. Osmanlı 
İmparatorluğunun Batı dünyası ile askeri ve kültürel alanda gelişen münasebetleri, Batı'dan Osmanlı'ya yönelik bir etkileşim sağlamış, böylece Türk aydınının kadın hakları meselesine eğilmeye başladığı görülmüştür. Bazı Osmanlı aydınları kadının eğitimi, sosyal ve ekonomik konulardaki hakları gibi konuları tartışmaya başlamışlardır.

Tanzimat döneminde kadınlara ilk defa eğitim hakkının tanınması, Türk kadınının çalışma hayatına girmesinin de önünü açmıştır. Yine bu dönemde, arazi mirasında ilk defa kadın, erkekle eşit haklara sahip olmuştur. Tanzimat döneminde atılan bu adımlar fikri alanda da kadın dergilerinin yayınlanmasına zemin hazırlamıştır. Meşrutiyet dönemi, Tanzimat'la başlayan faaliyetlerin ivme kazandığı bir dönem olmuştur. Yeni rejimin getirdiği serbestlik, kadın meseleleri ile ilgili tartışmaların rahatça yapılamasına zemin hazırlamıştır. Cumhuriyet dönemine kadar geçen bu süreç kadın meselesinde fikri temellerin oluşması bakımından önem taşımaktadır. Ancak kadın hakları konusunda köklü değişiklikler Cumhuriyet döneminde Medeni Kanunun (4 Nisan 1926) hazırlanması ile gerçekleşmiştir. Medeni Kanundan sonra kadınlara siyasal haklar verilmiş, 3 Nisan 1930 'da belediye seçimlerine katılma, 5 Aralık 1934 'de de milletvekili seçme seçilme hakkı tanınmıştır. Türkiye bu hakları tanıyan ilk İslam ülkesi olmuş ve 1934 seçimlerinde Meclise 18 kadın milletvekili seçilmiştir.

Türkiye'de çağdaşlaşma hareketinin, Türk toplumunu değiştiren etkileri, kendisini belki de en belirgin biçimde kadının toplum yaşamı içindeki yeni yerinin belirlenmesinde göstermiştir. Bunun en göze çarpıcı tarafı ise, Türk kadınının biçimsel değişiminin yanı sıra kamusal alanda aktif olarak üstlendiği roller olmuştur. Bu gelişmeler doğrultusunda Cumhuriyet dönemi basınında kadın haklarının önemini vurgulayan, kadınları bu konuda daha bilinçli bir hale getirme adına varlık gösteren yayınlar çıkmaya devam etmiştir. Bu dönemde kadın yayınları, kendilerine tanınan hakların aktif bir şekilde kullanılması için mücadele vermişler ve böylece Tanzimat ve Meşrutiyet dönemi kadın süreli yayınlarıyla farklarını ortaya koymuşlardır. 1 Mart 1947 yılında "Sosyal-Siyasi-İçtimai Kadın Gazetesi”" başlığı ile yayın hayatına başlayan Kadın Gazetesi ise kadın yayınları içinde bir anda öne çıkmışıı. İffet Halim Oruz, Hasene Ilgaz, Şuküfe Nihal, Zübeyde Mengüç, Neriman Tuna, Müjgân Ağaoğlu, Halide Nusret Zorlutuna gibi dönemin önemli aydın kadınları tarafından yayınlanan gazete Türk yayın hayatına kazandırılmıştır. Gazete, sosyal, hukuki ve siyasi alanlarda görülen kadın sorunlarına eğilerek kadının gündelik hayat içerisindeki varlığını etkin bir hale getirmeye çalışmıştır. Tüm bu yazarlar içerisinde en fazla ses getirenlerden biri İffet Halim Oruz olmuştur. Onun, yazıları aracılığıyla yaydığı fikirler, kendisinin önemli bir portre olmasına yol açmıştır. Oruz'un yazılarında en çok mücadele verdiği konu, cumhuriyet rejimi ile birlikte kadınlara tanınan hakların, fiiliyatta da uygulanmasını sağlamak olmuştur. Oruz'a göre kadın haklarının gelişimi ancak kadınların sahip oldukları haklar konusundaki farkındalıklarının artmasıyla gerçekleşecektir. Yazılarındaki çabası büyük oranda bu yönde olmuştur.

Kadınların bilinçlenmesi adına gündelik siyasi konulara da yazılarında yer veren Oruz, seçimlerden Meclis çalışmalarına değin çeşitli konulara değinmiştir. Böylelikle kadınların siyasette daha aktif şekilde yer alacakları düşünülmüştür. Siyasi konularda Atatürk döneminde kadınlara verilen hakların önemine yoğun şekilde değinen Oruz, Türk kadınının geldiği noktayı, dünyadaki başka örneklerle karşılaştırarak açıklama ihtiyacı hissetmiştir. Kadınların hayatın her alanındaki gelişimi adına gerek Kadın Gazetesi'nin gerçekleştirdiği gerekse de başka yerlerde gerçekleşen tüm faaliyetlere değinilmiş ve kadınlarda bir farkındalık yaratılmaya çalışılmıştır. Tüm bu çalışmalarının sonucunda İffet Halim Oruz ismi, Türkiye'de kadın özgürlüğü konusunda kendisine ön planda yer bulmayı başarmıştır.

\section{Kaynakça}

Akdağ (Koç), Ç. T. (2010). Modernleşme Yolunda Bir "Kadın Gazetesi”, İstanbul'da Fikir Gazeteciliği Sempozyumu, (21-22 Ekim 2010), 205-225.

Babalık, B. ve Erdoğan, D. (2016). Demokrat parti İktidarında Kadın Dergileri ve Kadın İmajı (1950-1954), Geçmişten Günümüze Şehir ve Kadın I, (E. O. Köse), Canik Bld. Kültür Yay. 
Balc1, M. ve Tuzak, M. (2017). Cumhuriyet'in İlk Yıllarında Nezihe Muhiddin Özelinde Türk Kadınlarının Siyasi Hakları İçin Mücadelesi, Marmara Üniversitesi Kadın ve Toplumsal Cinsiyet Araştırmaları Dergisi, I: 43-51.

Caporal, B. (1982). Kemalizm ve Kemalizm Sonrası Türk Kadını, Ankara: Türkiye İş Bankası Kültür Yayınları.

Çakır, S. (1996). Osmanlı Kadın Hareketi, İstanbul: Metis Yayınları.

Çalışkan, V. ve Özey, E. (2016). Darülfünun'dan Mezun İlk Kadın Coğrafyacı: Şükufe Nihal (1897-1973), Türk Coğrafya Dergisi, 67: 61-66.

Demircioğlu, C. (1998). Müfide Ferit Tek ve Romanlarındaki Milliyetçilik, Boğaziçi Üniversitesi Sosyal Bilimler Enstitüsü Basılmamış Yüksek Lisans Tezi.

Enginün İ, Canbur, M. ve Özdemir C. (1983). Milli Mücadelede Türk Kadını, Ankara: Türk Ticaret Bankası Yayınları.

Erdem, Y. T. ve Yiğit, H. (2010). Bacıyan-ı Rum'dan Günümüze Türk Kadınının İktisadi Hayattaki Yeri, İstanbul: İstanbul Ticaret Odası Yayınları.

Halide Hanımın Nutku, Alemdar, 24 Mayıs 1919.

İnsel, A. ve İlyasoğlu, D. (1984). Kadın Dergilerinin Evrimi, Türkiye'de Dergiler ve Ansiklopediler (1849-1984), İstanbul.

İzmir Hadisesi Etrafında, Halide Edip Hanımın Nutku, Yeni Gazete, 20 Mayıs 1919.

Kadıköylülerin Dünkü Muazzam Mitingi, Halide Edip Hanımın Nutku, Vakit, 23 Mayıs 1919.

Kanter, B. (2010). Osmanlı Basın Hayatında Kadın Yazarlar, Tercüman-ı Ahval'in 150. Yılında İstanbul'da Fikir Gazeteciliği Sempozyumu (Ed. B. Ulusoy).

Kaplan, L. (1998). Cemiyetlerde ve Siyasî Teşkilatlarda Türk Kadını (1908-1960), Ankara: Atatürk Araştırma Merkezi Yayınları.

Karabulut, U. (2012). Hukuk Alanındaki İnkılâplar, Inkılap Dersleri, 4.B., Ed: S. İnan, C. Akseki, Gökçe Yay. 225-231.

Karaca, Ş. (2011). Fatma Aliye Hanım'ın Türk Kadın Haklarının Düşünsel Temellerine Katkıları, Karadeniz Araştırmaları, Güz 2011, 93-111.

Karaca, Ş. (2011). Modernleşme Döneminde Bir Kadın Yazarın Portresi: Emine Semiye Hanım, Bilig, Bahar 2011/57, 115-134.

Koç, Ç.T. (2018). Modernleşme Sürecinde Batı'da ve Osmanlı'da Feminizm ve Kadın Dergileri (1869-1927), İstanbul: Gece Akademi.

Koç, Ç.T. (2018). The New York Times Gazetesi'nde (1922-1931) Halide Edib'le İlgili Yayınlanan Haberlerin İncelenmesi, İletişim Kuram ve Araştırma Dergisi, 46: 306-322.

Köse, E. (2006). Iffet Halim Oruz'un Hayatı, Sanatı ve Eserleri, Atatürk Üniversitesi, Sosyal Bilimler Enstitüsü, Basılmamış Yüksek Lisans Tezi.

Kurnaz, Ş. (1991). Cumhuriyet Öncesinde Türk Kadını (1839-1923), 2. Bask1, Ankara: T.C. Başbakanlık Aile Araştırma Kurumu Başkanlığı Yayınları.

Kurnaz, Ş. (2008). Osmanlı Kadın Hareketinde Bir Öncü Emine Semiye, İstanbul: Timaş Yay.

Oruz, İ. H. (1986). Türkiye'de Kadın Devrimi, İstanbul: Gül Matbaası.

Oruz, İ. H. 1950 Seçimlerinde Kadınlara Düşen Görevler, Kadın Gazetesi, 27 Mart 1950.

Oruz, İ. H. Cumhuriyet Kadını, Kadın Gazetesi, 17 Kasım 1947. 
Oruz, İ. H. Davalarımız, Kadın Gazetesi, 22 Mart 1947.

Oruz, İ. H. Din ve Dil Meselelerine Dair, Kadın Gazetesi, 17 Temmuz 1950.

Oruz, İ. H. Eğitim Projesi, Kadın Gazetesi, 13 Aralık 1948.

Oruz, İ. H. Kadın Gazetesi Eğitim Toplantısı, Kadın Gazetesi, 10 Ocak 1949.

Oruz, İ. H. Kadın Gazetesi”, Kadın Gazetesi, 1 Mart 1947.

Oruz, İ. H. Kadın Gazetesinin Bir Yıllık Çalışmaları Dolayısıyla, Kadın Gazetesi, 1 Mart 1948.

Oruz, İ. H. Kadın Gözüyle, Kadın Gazetesi, 26 Ocak 1948.

Oruz, İ. H. Kız Enstitüleri, Kadın Gazetesi, 14 Haziran 1948.

Oruz, İ. H. Moda ve Lüks, Kadın Gazetesi, 12 Temmuz 1947.

Oruz, İ. H. Onyedinci Yayın Y111, Kadın Gazetesi, 4 Mart 1963.

Oruz, İ. H. Türk Kadın Birliği, Kadın Gazetesi, 16 Mayıs 1949.

Oruz, İ. H. Türk Kadın İnkılabı Hakkında Yanlış Görüşler, Kadın Gazetesi, 7 Kasım 1949.

Oruz, İ. H. Yeniden Seçim Yapılırsa, Kadın Gazetesi, 6 Ekim 1947.

Tansel, F. A. (1987). Memleketimizde Gençler İçin Kurulan İlk Dernekler, Gazete ve Dergiler, Belleten, LI/199, s. 281-304.

Tekeli, Ş. (1979). Türkiye'de Kadının Siyasal Hayattaki Yeri, Türk Toplumunda Kadın (Ed.N.A. Unat), Ankara: Türk Sosyal Bilimler Derneği.

Tekeli, Ş. (1982). Kadınlar ve Siyasal Toplumsal Hayat, İstanbul: Birikim Yayınları.

Tekeli, Ş. (1988). Kadınlar İçin, İstanbul: Alan Yayıncılık.

Toprak, Z. (2014). Türkiye'de Kadın Özgürlüğ̈̈ ve Feminizm (1908-1935), İstanbul: Tarih Vakfi Yurt Yayınları.

Ünal, B (2010). Türk Kadınlı̆̆ İçin Çağdaş Bir Adım: Kadın Gazetesi (1947-1951), Selçuk Üniversitesi Sosyal Bilimler Enstitüsü Basılmamış Yüksek Lisans Tezi.

Üsküdar Hanımlarının Tezahüratı, Alemdar, 19 Mayıs 1919.

Zihnioğlu, Y (2003). Kadınsız Inkılâp Nezihe Muhiddin, Kadınlar Halk Fırkası, Kadın Birliği, İstanbul: Metis Yayınlar1.

\section{Süreli Yayınlar}

Alemdar

Cumhuriyet Kadinı

$E v-\dot{I}_{S}$

Ev-Kadin

Kadın Dünyası

Kadın Gazetesi

Kadın Yazıları

Türk Kadını

Vakit

Yeni Gazete 